\title{
Interactions of the Effects of Provenances and Habitats on the Growth of Scots Pine in Two Provenance Tests in Bosnia and Herzegovina
}

\author{
Mirzeta Memišević Hodžići,*, Dalibor Ballian ${ }^{1,2}$
}

(1) University of Sarajevo, Faculty of Forestry, Department of Silviculture and Urban Greenery, Zagrebačka 20, BA-71000 Sarajevo, Bosnia and Herzegovina; (2) Slovenian Forestry Institute, Večna pot 2, SI-1000 Ljubljana, Slovenia

* Correspondence: e-mail: $\underline{\text { m.memisevic-hodzic@sfsa.unsa.ba }}$
Citation: Memišević Hodžić M, Ballian D, 2021. Interactions of the Effects of Provenances and Habitats on the Growth of Scots Pine in Two Provenance Tests in Bosnia and Herzegovina. Southeast Eur for 12(1): 13-20. https://doi. org/10.15177/seefor.21-03.

Received: 11 Jan 2021; Revised: 9 Mar 2021; Accepted: 12 Mar 2021; Published online: 11 Apr 2021

\begin{abstract}
This research aims to determine the interaction of the effects of provenance and habitat conditions on provenance tests on the growth of Scots pine on two experimental plots in Bosnia and Herzegovina. Provenance tests are located on plots with different ecological conditions and altitudes: Romanija Glasinac, $1000 \mathrm{~m}$, and Gostović Zavidovići, $480 \mathrm{~m}$. Both tests include 11 provenances and two clonal seed plantations with 10 families in each, and five repetitions. Tree heights and diameters at breast height were measured at the age of 21 years. Interactions were determined using multivariate analysis for measured traits. The highest average heights on the provenance test Glasinac had provenances Bugojno, Romanija Glasinac, and Šipovo $(8.8 \mathrm{~m})$, and on the Gostović provenance Rogatica $(11.0 \mathrm{~m})$. The highest average diameter at breast height on the Glasinac test had Šipovo provenance $(13.9 \mathrm{~cm})$ and on the Gostović test Bosanski Petrovac provenance $(12.3 \mathrm{~cm})$. Variance analysis showed statistically significant differences among provenances in terms of diameter at breast height and height values. Multivariate analysis showed the presence of interactions of effects of provenances and habitat conditions on provenance tests. For provenances that did not show interaction, it is recommended to use provenances that performed better in the given ecological conditions, and for those that showed interaction, it is necessary to choose those provenances which are expected to show better results in given conditions later in life. The obtained results are very important for the conservation activities of this species.
\end{abstract}

Keywords: Pinus sylvestris; morphological traits; genetic structure; environmental conditions

\section{INTRODUCTION}

Scots pine (Pinus sylvestris L.) is one of the most important tree species in European forests. It is characterized by high genetic variability and complex population structure (Stefanović et al. 1980, Omanović 2008). In Bosnia and Herzegovina, differences within Scots pine populations can be expected at the morphological level (Stefanović 1980). Differences can be expected in the production potential of provenances as well (Mikić 1991). Due to the importance of this species for the forestry of Bosnia and Herzegovina, clonal seed plantations were established (Ballian and Božić 2004, Ballian et al. 2005), two of which were used in this research.
Knowing whether a species has resilience and adaptability to changing environmental conditions, as well as stress conditions, is important for the functioning of modern forestry and conservation of forest ecosystems. Higher genetic variability makes the species more resilient and better adapted for survival in changing environmental conditions and in stress conditions (Villani and Eriksson 2006).

There have not been many studies on the interactions between the effects of provenance genetic structure and habitat conditions on Scots pine. Some authors studied morphological traits of Scots pine in international provenance tests in Poland (Barzdajn et al. 2016), Spain (Alía et al. 2001), Turkey (Gülcü and Bilir 2017), and in 
Bosnia and Herzegovina (Ballian et al. 2009, Cvjetković et al. 2014, Ballian and Šito 2017, Ballian et al. 2019). Taeger et al. (2013) studied the impact of climate and drought events on the growth of Scots pine provenances in an international provenance test which also contained a provenance from Bosnia and Herzegovina, and the results indicate a better adaptation to drought of the provenance from Bosnia Herzegovina and of local German provenances compared to other provenances.

Unfortunately, so far there has been little research dealing with provenance interactions. So far, interactions among provenances originating from different countries, from a greater geographical distance (Memišević Hodžić et al. 2020), but not provenances from a narrower geographical area such as Bosnia and Herzegovina, have been analyzed. Thus, Memišević Hodžić et al. (2020) studied the interaction between the effects of provenance genetic structure and habitat conditions on international provenance tests of Scots pine in two locations in Bosnia and Herzegovina. Obtained results indicated interactions on some provenances.

For studying the variability and adaptability of Scots pine in Bosnia and Herzegovina, provenance tests were established in 1988 on two locations, Romanija Glasinac and Zavidovići Gostović. The study aims to determine whether there is an interaction between the effects of provenance genetic structure and habitat conditions on the growth of Scots pine in both test plots, for selection and breeding of provenances adapted to habitat conditions.

\section{MATERIALS AND METHODS}

In this paper, the material from two provenance tests of Scots pine in Bosnia and Herzegovina was investigated. Information about the locations of test plots are shown in Table 1.
Provenance tests were established from seed material from 11 seed stands of Scots pine and two clonal seed plantations (Sarajevo-Rakovica and Doboj-Stanovi). A random block system was applied, and the distribution of provenances was the same at both provenance tests. The seeds were sown in 1986 in the nursery "Slatina" of the Faculty of Forestry in Sarajevo. At the age of two years (1+ $1)$, seedlings were planted in two experimental plots, with planting spacing of $2 \times 2 \mathrm{~m}$. Each provenance within the plot was composed of ten families with four plants, and each provenance was planted in five replications. The list of provenances and information about their locations is shown in table 2 and their geographical distribution in figure 1.

In the spring of 2007, plant heights and diameters at breast height were measured. Data were processed using the statistical program SPSS 26.0. Descriptive and multivariate analyses (Two-way ANOVA) were performed. Two-way ANOVA shows whether there is an interaction of two independent factors (provenance and habitat) on the dependent variable (height and diameter). In other words, it shows whether the influence of one of the independent variables on the dependent variable is the same for all values of the second independent variable (and vice versa).

\section{RESULTS}

Average values of height per provenances and provenance tests are shown in Figure 2. All provenances had higher values of average heights on the Gostović than on the Glasinac plot. The highest average heights on the Glasinac plot had provenances Bugojno, Romanija Glasinac, and Šipovo $(8.8 \mathrm{~m})$, and on the Gostović plot provenance Rogatica $(11.0 \mathrm{~m})$. The lowest average height on the Glasinac plot had Olovo and Zavidovići provenances $(7.3 \mathrm{~m})$, and on the Zavidovići plot seed plantation Doboj had the lowest average height $(9.0 \mathrm{~m})$.

Table 1. Information about Scots pine provenance tests' locations.

\begin{tabular}{lcc}
\hline Information / Provenance test & Romanija Glasinac & Zavidovići Gostović \\
\hline North Latitude & $43^{\circ} 52^{\prime} 43.10^{\prime \prime}$ & $44^{\circ} 20^{\prime} 55.27^{\prime \prime}$ \\
East Longitude & $18^{\circ} 50^{\prime} 31.34^{\prime \prime}$ & $18^{\circ} 08^{\prime} 04.03^{\prime \prime}$ \\
Forest Management Area & "Sokolačko“ & "Krivajsko" \\
Management Unit & "Romanija Glasinac" & "Gostović" \\
Department & 15 & 42 \\
Altitude & $1000 \mathrm{~m}$ & $480 \mathrm{~m}$ \\
Exposition & $\mathrm{E}$ & SW \\
Inclination & $5^{\circ}$ & $20^{\circ}$ \\
Geological substrate & Limestone \\
Soil type & Calcomelanosol & Serpentine-peridotite \\
Vegetation & Piceo Pinetum illyricum pyroletosum & Ranker, eutric cambisol \\
Average annual temperature & $7.08^{\circ} \mathrm{C}$ & Pinetum silvestris nigrea serpentinicum \\
Vegetation period duration & 157 days & $9.35^{\circ} \mathrm{C}$ \\
\hline
\end{tabular}


Table 2. List and location information of provenances in the provenance test.

\begin{tabular}{lccccc}
\hline \multicolumn{1}{c}{ Provenance } & $\begin{array}{c}\text { North } \\
\text { Latitude }\end{array}$ & $\begin{array}{c}\text { East } \\
\text { Longitude }\end{array}$ & $\begin{array}{c}\text { Altitude } \\
(\mathrm{m})\end{array}$ & Soil type & Geological substrate \\
\hline Bosanski Petrovac & $44^{\circ} 29^{\prime} 28^{\prime \prime}$ & $16^{\circ} 29^{\prime} 21^{\prime \prime}$ & 920 & rendzina & dolomite, limestone \\
Bugojno & $44^{\circ} 03^{\prime} 10^{\prime \prime}$ & $17^{\circ} 19^{\prime} 55^{\prime \prime}$ & 1230 & dolomite rendzina & dolomite \\
Foča & $43^{\circ} 20^{\prime} 51^{\prime \prime}$ & $18^{\circ} 56^{\prime} 25^{\prime \prime}$ & 1370 & distric cambisol & quartzporphyrite \\
Han Kram & $44^{\circ} 01^{\prime} 53^{\prime \prime}$ & $18^{\circ} 56^{\prime} 32^{\prime \prime}$ & 1100 & swampy, charred, brown podzolic & tuff sandstones \\
Kladanj & $44^{\circ} 16^{\prime} 46^{\prime \prime}$ & $18^{\circ} 37^{\prime} 47^{\prime \prime}$ & 900 & district cambisol and brown & sodzolic soil \\
Olovo & $44^{\circ} 14^{\prime} 50^{\prime \prime}$ & $18^{\circ} 20^{\prime} 54^{\prime \prime}$ & 850 & eutric cambisol & peridotite \\
Rogatica & $43^{\circ} 48^{\prime} 06^{\prime \prime}$ & $19^{\circ} 08^{\prime} 32^{\prime \prime}$ & 1100 & distric cambisol, luvisol & cherts \\
Romanija - Glasinac & $43^{\circ} 54^{\prime} 20^{\prime \prime}$ & $18^{\circ} 42^{\prime} 50^{\prime \prime}$ & 1235 & calcocambisol & limestone \\
Romanija - Palež & $44^{\circ} 02^{\prime} 14^{\prime \prime}$ & $18^{\circ} 45^{\prime} 50^{\prime \prime}$ & 780 & pseudogley & diabase gabbro \\
Seed plantation Doboj & $44^{\circ} 45^{\prime} 11^{\prime \prime}$ & $17^{\circ} 59^{\prime} 50^{\prime \prime}$ & 180 & fluvisol & sandstone \\
Seed plantation Sarajevo & $43^{\circ} 52^{\prime} 14^{\prime \prime}$ & $18^{\circ} 12^{\prime} 52^{\prime \prime}$ & 570 & clay, ortstein & marl \\
Šipovo & $44^{\circ} 14^{\prime} 31^{\prime \prime}$ & $17^{\circ} 13^{\prime} 26^{\prime \prime}$ & 1200 & dolomite rendzina, calcocambisol & dolomite, limestone \\
Zavidovići & $44^{\circ} 19^{\prime} 56^{\prime \prime}$ & $18^{\circ} 12^{\prime} 44^{\prime \prime}$ & 480 & ranker, eutric cambisol & serpentine peridotite \\
\hline
\end{tabular}

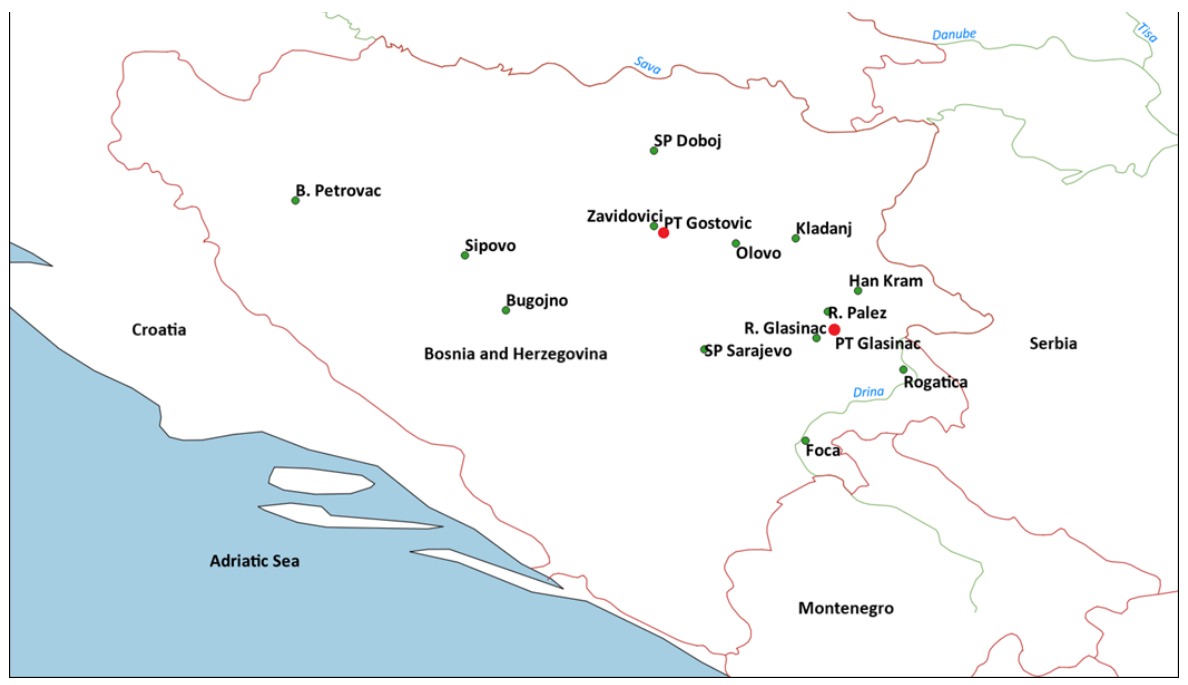

Figure 1. Provenances included in provenance tests Glasinac and Gostović (SP - seed plantation; PT - provenance test).

Average values of breast height diameter per provenances are shown in Figure 3. Unlike for the trait of height, all provenances had higher average values of diameter at breast height on the Glasinac than on the Gostović plot. The highest average breast diameter on the Glasinac plot had Šipovo provenance $(13.9 \mathrm{~cm})$ and on the Gostović plot Bosanski Petrovac provenance $(12.3 \mathrm{~cm})$. The lowest average values of breast height diameter on the Glasinac plot had provenance Olovo $(11.9 \mathrm{~cm})$ and on the Gostović plot seed plantation Doboj $(9.8 \mathrm{~cm})$.

In the multivariate tests table for height and diameter at breast height together (Table 3 ) it is visible that Wilks' Lambda showed Sig. value of 0.000 , which indicates $p<$
0.0005 for both factors and interaction between factors. It means that values of heights and diameters at breast height are significantly dependent on provenances, habitat conditions on provenance tests, and interaction of provenances and habitat conditions on provenance tests.

Considering that an interaction effect can usually be seen as a set of non-parallel lines, it is visible in Figure 4 that there is a statistically significant interaction of effects of provenance and environmental conditions on experimental plots for the trait of height for some of the researched provenances. The provenance of seed plantation Doboj was most clearly distinguished by the interaction of provenance $x$ habitat, with estimated marginal mean of height among 


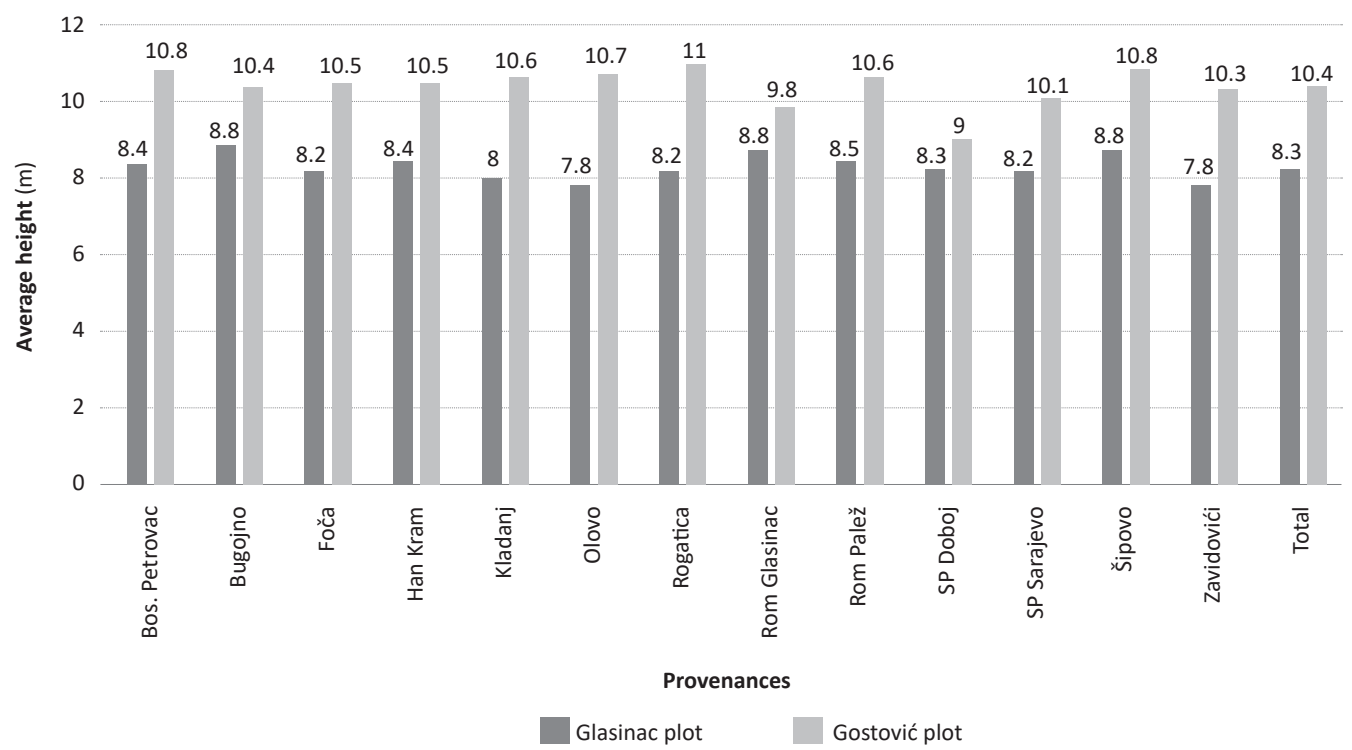

Figure 2. Average values of height of plants per provenances and experimental plots.

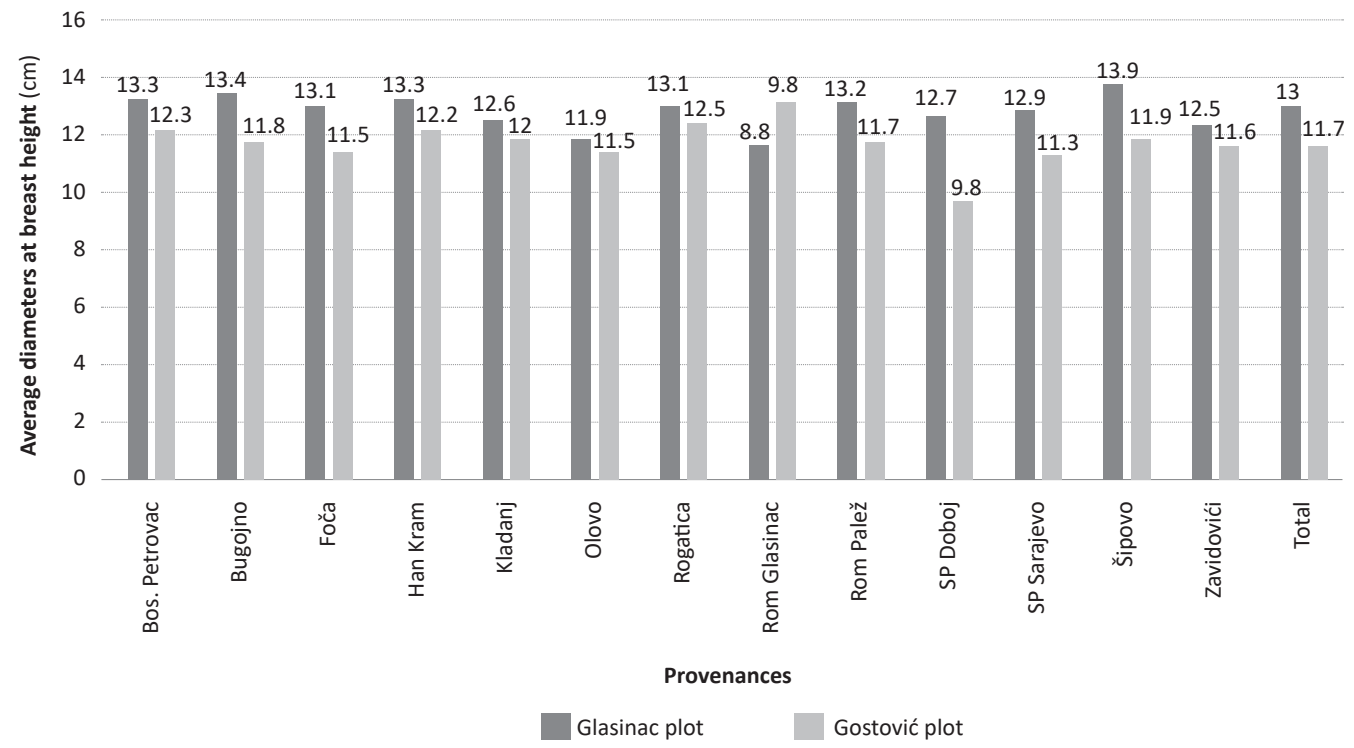

Figure 3. Average values of breast height diameter of plants per provenances and tests.

other provenances on Glasinac, but lower than other provenances on the Gostović plot. Provenance Romanija Glasinac had one of the highest estimated marginal means on the Glasinac plot, but one of the lowest marginal means on the Gostović plot. Provenance Rogatica had estimated marginal mean of height about average for all provenances on the Glasinac plot, but the highest estimated marginal mean on the Gostović plot. Provenance Šipovo had the highest estimated marginal mean for height on the Glasinac plot, and one of the highest marginal means on the Gostović plot. Provenances Zavidovići and Olovo had the lowest estimated marginal means for height on the Glasinac plot, but on the Gostović plot, their values were among the values of other provenances.

Tests of between-subjects effects table (Table 4) for the trait of height showed the presence of statistically significant interaction between provenances and habitat conditions (Fizr.>Ftab., Sig.<0.005).

In the graphical representation of estimated marginal means for the trait of diameter at breast height (Figure 5), 
Table 3. Results of multivariate testsa for the height and diameter at breast height.

\begin{tabular}{|c|c|c|c|c|c|c|}
\hline \multicolumn{2}{|c|}{ Effect } & \multirow{2}{*}{$\begin{array}{l}\text { Value } \\
0.961\end{array}$} & \multirow{2}{*}{$\frac{F}{45238.595^{b}}$} & \multirow{2}{*}{$\begin{array}{c}\text { Hypothesis df } \\
2.000\end{array}$} & \multirow{2}{*}{$\begin{array}{l}\text { Error df } \\
3651.000\end{array}$} & \multirow{2}{*}{$\begin{array}{l}\text { Sig. } \\
0.000\end{array}$} \\
\hline \multirow{4}{*}{ Intercept } & Pillai's Trace & & & & & \\
\hline & Wilks' Lambda & 0.039 & $45238.595^{b}$ & 2.000 & 3651.000 & 0.000 \\
\hline & Hotelling's Trace & 24.781 & $45238.595^{b}$ & 2.000 & 3651.000 & 0.000 \\
\hline & Roy's Largest Root & 24.781 & $45238.595^{b}$ & 2.000 & 3651.000 & 0.000 \\
\hline \multirow{4}{*}{ Provenance test } & Pillai's Trace & 0.541 & $2150.029^{b}$ & 2.000 & 3651.000 & 0.000 \\
\hline & Wilks' Lambda & 0.459 & $2150.029^{b}$ & 2.000 & 3651.000 & 0.000 \\
\hline & Hotelling's Trace & 1.178 & $2150.029^{b}$ & 2.000 & 3651.000 & 0.000 \\
\hline & Roy's Largest Root & 1.178 & $2150.029^{b}$ & 2.000 & 3651.000 & 0.000 \\
\hline \multirow{4}{*}{ Provenance } & Pillai's Trace & 0.030 & 4.656 & 24.000 & 7304.000 & 0.000 \\
\hline & Wilks' Lambda & 0.970 & $4.669^{b}$ & 24.000 & 7302.000 & 0.000 \\
\hline & Hotelling's Trace & 0.031 & 4.682 & 24.000 & 7300.000 & 0.000 \\
\hline & Roy's Largest Root & 0.025 & $7.655^{c}$ & 12.000 & 3652.000 & 0.000 \\
\hline \multirow{4}{*}{$\begin{array}{l}\text { P. test * } \\
\text { Provenance }\end{array}$} & Pillai's Trace & 0.030 & 4.690 & 24.000 & 7304.000 & 0.000 \\
\hline & Wilks' Lambda & 0.970 & $4.713^{b}$ & 24.000 & 7302.000 & 0.000 \\
\hline & Hotelling's Trace & 0.031 & 4.736 & 24.000 & 7300.000 & 0.000 \\
\hline & Roy's Largest Root & 0.028 & $8.602^{c}$ & 12.000 & 3652.000 & 0.000 \\
\hline
\end{tabular}

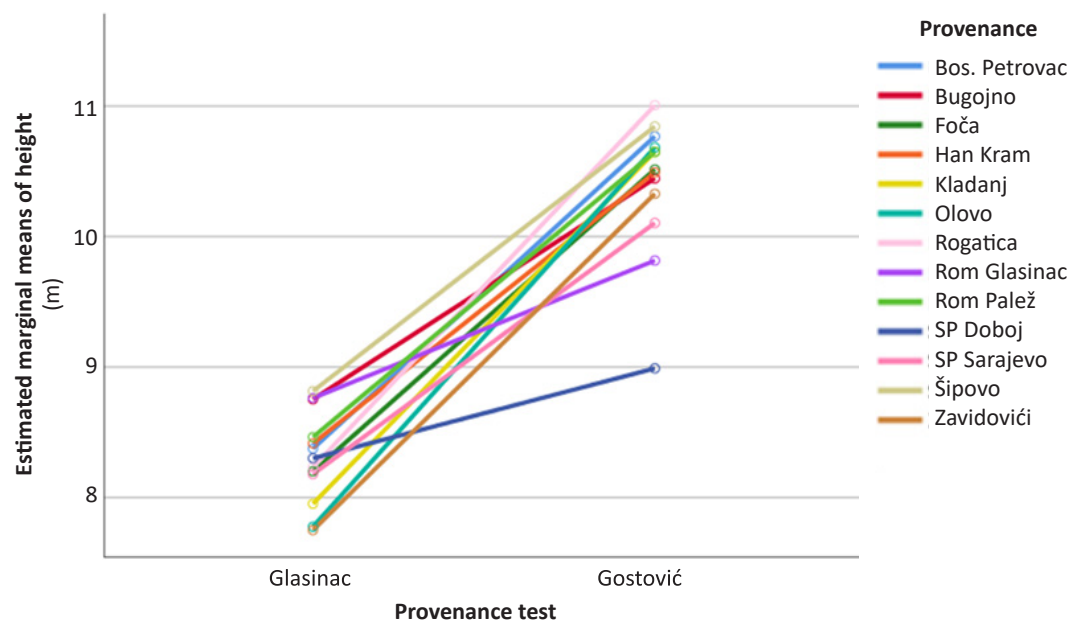

Figure 4. Graph of the interaction of effects of provenance and habitat conditions for height

it is visible that there is a statistically significant interaction between provenance and environmental conditions of experimental plots for some of the researched provenances. Similar to the trait of height, the provenance of seed plantation Doboj was most clearly distinguished by the interaction of provenance $x$ habitat for the breast height diameter, with estimated marginal mean among other provenances on Glasinac, but lower than other provenances on the Gostović plot. Provenance Romanija Glasinac had one of the highest estimated marginal means on the Glasinac plot, but one of the lowest marginal means on the Gostović plot. Provenance Rogatica had estimated marginal mean of diameter at breast height about average for all provenances on the Glasinac plot, but the highest estimated marginal mean on the Gostović plot. Provenance Šipovo had the highest estimated marginal mean for diameter at breast height on the Glasinac plot, and one of the highest marginal means on the Gostović plot. Provenance Olovo had the lowest estimated marginal mean for diameter at breast height on the Glasinac plot, but on the Gostović plot, its value was among the values of other provenances.

Tests of between-subjects effects table (Table 5) for the trait of breast height diameter showed that there is a statistically significant interaction of effects of provenances and habitat conditions on provenance tests conditions (Fizr.>Ftab., Sig.<0.005). 


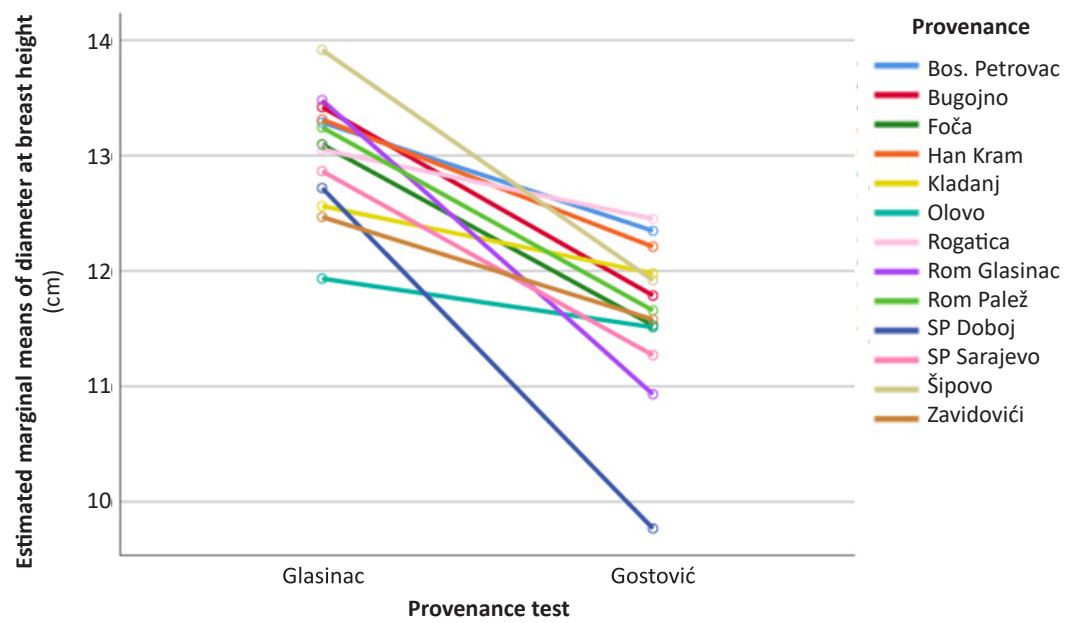

Figure 5. Graph of the interaction of effects of provenance and habitat conditions for diameter at breast height.

Table 4. Tests of between-subjects effects for trait of height.

\begin{tabular}{lcrrrr} 
& Type III Sum of Squares & df & Mean Square & F & Sig. \\
\hline Corrected Model & $4796.276^{\mathrm{a}}$ & 25 & 191.851 & 54.368 & 0.000 \\
Intercept & 318609.332 & 1 & 318609.332 & 90290.226 & 0.000 \\
Provenance test & 4015.689 & 1 & 4015.689 & 1138.000 & 0.000 \\
Provenance & 311.826 & 12 & 25.986 & 7.364 & 0.000 \\
P. test * Provenance & 358.017 & 12 & 29.835 & 8.455 & 0.000 \\
Error & 12886.902 & 3652 & 3.529 & & \\
Total & 342382.930 & 3678 & & & \\
Corrected Total & 17683.178 & 3677 & & &
\end{tabular}

R Squared $=.271$ (Adjusted R Squared $=0.266$ )

Table 5. Tests of between-subjects effects for diameter at breast height.

\begin{tabular}{|c|c|c|c|c|c|}
\hline Source & Type III Sum of Squares & df & Mean Square & $\mathbf{F}$ & Sig. \\
\hline Corrected Model & $2970.403^{b}$ & 25 & 118.816 & 11.473 & 0.000 \\
\hline Intercept & 552301.877 & 1 & 552301.877 & 53329.602 & 0.000 \\
\hline Provenance test & 1824.163 & 1 & 1824.163 & 176.139 & 0.000 \\
\hline Provenance & 768.520 & 12 & 64.043 & 6.184 & 0.000 \\
\hline P. test * Provenance & 496.316 & 12 & 41.360 & 3.994 & 0.000 \\
\hline Error & 37821.517 & 3652 & 10.356 & & \\
\hline Total & 599746.103 & 3678 & & & \\
\hline Corrected Total & 40791.920 & 3677 & & & \\
\hline
\end{tabular}

\section{DISCUSSION}

Investigating the interactions of the effects of provenances and environmental conditions can be important in the breeding strategy of Scots pine.
In this research, statistically significant interactions of effects of provenance and environmental conditions on experimental plots for both traits and some of the researched provenances were found. Provenance Romanija Glasinac had one of the highest estimated marginal 
means for height on the Glasinac plot, but one of the lowest marginal means on the Gostović plot. It could be explained by the vicinity of the provenance origin to the provenance test and similar ecological conditions. Provenances Zavidovići and Olovo had the lowest estimated marginal means for height on the Glasinac plot, but on the Gostović plot, their values were among the values of other provenances, which can also be explained by the vicinity of the provenances and similarity of their ecological conditions with the provenance test Gostović. Similar to the trait of height, provenance Romanija Glasinac had one of the highest estimated marginal means for diameter at breast height on the Glasinac plot, but one of the lowest marginal means on the Gostović plot. Provenance Rogatica had estimated marginal mean of diameter at breast height about average for all provenances on the Glasinac plot, but the highest estimated marginal mean on the Gostović plot. Provenance Olovo had the lowest estimated marginal mean for height on the Glasinac plot, but on the Gostović plot, its value was among the values of other provenances.

These results correspond to the results of other researchers. Eiche and Andersson (1974) investigated survival and growth in Scots pine in provenance tests in Northern Sweden. Their results showed the genecological variation of climatic hardiness, capacity for survival, and growth rate of different populations. They concluded that interaction for genotype and environment emerged quite obviously. Matheson and Raymond $(1984,1986)$ stated that the provenance by site interactions in forest trees are often detectable, but of small importance. Savva and Vaganov (2006) assessed genetic and environmental effects in Scots pine provenances planted in Central Siberia. They found that the main climatic factors controlling tree-rings formation differed slightly among different provenances. The genetically fixed ability of the provenances was not great (less than 15\%), which proves the high adaptability of Scots pine to abrupt climatic change. The tree-ring formation of Scots pine provenances is mainly determined by environmental factors. Zhelev and Lust (1999) investigated Scots pine provenances in Belgium and found that the provenance by site interactions was of importance only for height growth. Alía et al. (2001) investigated 16 Spanish and 6 German provenances of Scots pine in a provenance test in Spain. Based on data for the height, diameter, the number of twigs at the fourth year whorl, and survival, provenance by site interaction was very significant $(P<$ 0.01 ) for most traits.

Ballian et al. (2009) measured the diameter and height of the plants and calculated basal area and volume of plants in the provenance test of Scots pine Glasinac Sokolac, which is one of the provenance tests in this research. The provenance geographically closest to the provenance test showed the best results of productivity. Cvjetković et al. (2014) measured and calculated the same characteristics at the same plot in 2011. The results confirmed the existence of significant differences within and among provenances, and the provenance geographically closest to the provenance test showed the best results. In this research, provenance Romanija Glasinac, closest to the provenance test Glasinac Sokolac, showed the highest average height, but not the highest average of breast height diameter.
Gülcü and Bilir (2017) studied provenance $x$ site interactions in thirteen-year-old Scots pine provenance tests at two sites in the southern part of Turkey, containing 30 provenances, based on height, diameter, and survival of plants. The results showed statistically significant provenance $\mathrm{x}$ site interaction $(p<0.05)$. Memišević Hodžić et al. (2020) studied provenance $x$ site interaction in two international provenance tests in Bosnia and Herzegovina, based on the data of heights and root collar diameter, and determined interaction between some of the researched provenances.

\section{CONCLUSIONS}

The results of this research showed interaction of effects of provenance genetic structure and habitat conditions for both researched traits (height and diameter at breast height). Considering the height, provenances Bugojno, Romanija Glasinac, and Šipovo had the highest, and provenances Olovo and Zavidovići the lowest values on the Glasinac provenance test. On the Gostović test, provenance Rogatica had the highest, and Seed plantation Doboj the lowest value of height. The highest values of breast diameter on the Glasinac provenance test had Šipovo provenance and the lowest Olovo provenance. On the Gostović test, provenance Bosanski Petrovac had the highest values of breast height diameter, and the lowest had Seed plantation Doboj. Except for provenance Romanija Glasinac on the Glasinac test for the trait of height, provenances originated from locations nearest to the provenance test locations did not show higher values of researched traits. Wilks' Lambda multivariate tests showed that values of heights and diameters at breast height are significantly dependent on provenance, habitat conditions on provenance tests locations, and interaction of provenance $x$ habitat conditions on provenance tests locations. Graphical representation of estimated marginal means for both researched traits showed the presence of statistically significant interaction of effects of provenance and environmental conditions on provenance tests for some of the researched provenances. Tests of between-subjects effects for both traits showed a statistically significant interaction of effects of provenances and habitat conditions on provenance tests. The results of this study can be used in the process of Scots pine breeding and for its conservation by in situ and ex-situ methods.

\section{Author Contributions}

$\mathrm{MMH}, \mathrm{DB}$, conceived and designed the research, DB carried out the field measurements, DB performed measuring, $\mathrm{MMH}$ processed the data and performed the statistical analysis, DB supervised the research and helped to draft the manuscript, $\mathrm{MMH}$ wrote the manuscript.

\section{Funding}

This research received no external funding.

\section{Conflicts of Interest}

The authors declare no conflict of interest. 


\section{REFERENCES}

Alía R, Moro-Serrano J, Notivol E, 2001. Genetic variability of Scots pine (Pinus sylvestris) provenances in Spain: growth traits and survival. Silva Fenn 35(1): 27-38. https://doi.org/10.14214/sf.601.

Ballian D, Bogunić F, Konnert M, 2005. Usporedba molekularno genetičkih svojstava sjemenskih plantaža običnog bora (Pinus sylvestris L.) u Bosni i Hercegovini. Rad Šumar Ins. Jastrebarsko 41(2): 7-16

Ballian D, Božič G, 2004. Kontrola morfološke identifikacije klonova iz sjemenske plantaže bijelog bora "Koziji grm" pomoću izoenzimskih markera. Radovi Šum Fak Sarajevo 1: 47-56.

Ballian D, Lizdo E, Bogunić F, 2019. Analiza diferenciranosti rasta i fenologije provenijencija običnog bora (Pinus sylvestris L.) u pokusu provenijencija kod Kupresa (Bosna i Hercegovina). Sumar List 143(1-2): 25-34. https://doi.org/10.31298/sl.143.1-2.3.

Ballian D, Mujanović E, Čabaravdić A, 2009. Varijabilnosti običnog bora (Pinus sylvestris L.) u pokusu provenijencija Glasinac Sokolac, Bosna i Hercegovina. Sumar List 133(11-12): 577-588.

Ballian D, Šito S, 2017. Analysis of differences of growth and phenology of provenances of Scots pine (Pinus sylvestris) in provenance experiment at Žepče. Biosyst Divers 25(3): 228-235. https://doi.org/10.15421/011735.

Barzdajn W, Kowalkowski W, Chmura DJ, 2016. Variation in growth and survival among European provenances of Pinus sylvestris in a 30-year-old experiment. Dendrobiology 75: 67-77. https://doi. org/10.12657/denbio.075.007.

Cvjetković B, Mataruga M, Dukić V, Daničić V, Lučić A, 2014. The variability of Scots pine (Pinus sylvestris L.) in the provenance test in Bosnia and Herzegovina. In: Proceedings of the Biennial International Symposium Forest and Sustainable Development, Brasov, Romania, 24-25 October 2014. Transilvania University Press, Brasov, Romania, pp 79-88.

Giertych M, Matyas C, 1991. Genetics of Scots pine. Developments of Plant Genetics and Breeding. Vol 3. Elsevier, Amsterdam, Netherlands, $280 \mathrm{p}$.

Eiche V, Andersson E, 1974. Survival and Growth in Scots Pine (Pinus silvestris L.) Provenance Experiments in Northern Sweden. Theoret App/ Genetics 44: 49-57. https://doi.org/10.1007/BF00277952.

Gülcü S, Bilir N, 2017. Growth and Survival Variation among Scots Pine (Pinus sylvestris L.) Provenances. Int J Genomics. https://doi. org/10.1155/2017/1904623.
Matheson AC, Raymond CA, 1984. Provenance $x$ environment interaction: its detection, practical importance and use with particular reference to tropical forestry. In: Barnes RD, Gibson GL (eds) Commonwealth Forestry Institute, Oxford, and Forest Research Center, Harare, pp 81-117.

Matheson AC, Raymond CA, 1986. A review of provenance $x$ environment interaction: its practical use with particular reference to the tropics. Commonw Forest Rev 65(4): 283-302.

Memišević Hodžić M, Bejtić S, Ballian D, 2020. Interaction Between the Effects of Provenance Genetic Structure and Habitat Conditions on Growth of Scots Pine in International Provenance Tests in Bosnia and Herzegovina. South-east Eur for 11(1): 1116. https://doi.org/10.15177/seefor.20-03.

Mikić T, 1991. Primjena metoda oplemenjivanja u podizanju intezivnih kultura šumskog drveća u cilju povećanja proizvodnje drvne mase sa kratkim produkcionim periodom. Izvještaj za period 1989-1990 u okviru D.C.VII.Sarajevo.

Omanović M, 2008. Biohemijska karakterizacija prirodnih populacija običnog bora (Pinus sylvestris L.) u dijelu rasprostranjenja u Bosni i Hercegovini. MSc Thesis, University of Sarajevo, Faculty of Forestry Sarajevo, Bosnia and Herzegovina.

Savva JV, Vaganov EA, 2006. Genetic and Environmental Effects Assessment in Scots Pine Provenances Planted in Central Siberia. Mitig Adapt Strat Glob Change 11: 269-290. https://doi. org/10.1007/s11027-006-1026-2.

Stefanović V, Milanović S, Međedović S, Pintarić K, Rončević S, Sisojević D, 1980. Ekotipovi bijelog bora (Pinus sylvestris L.) u Bosni. Spec.ed. no 13. Faculty of Forestry and Forestry Institute, Sarajevo, Bosnia and Herzegovina, pp 9-25.

Taeger S, Zang C, Liesebach M, Schneck V, Menzel A, 2013. Impact of climate and drought events on the growth of Scots pine (Pinus sylvestris L.) provenances. Forest Ecol Manag 307: 30-42. https:// doi.org/10.1016/i.foreco.2013.06.053.

Villani F, Eriksson G, 2006. Conservation and management of European chestnut (Castanea sativa L.) genetic resources: outputs of the CASCADE project. EUFORGEN Noble Hardwoods Network, Report of the sixth (9-11 June 2002, Alter do Chao, Portugal) and seventh meetings (22-24 April 2004, Arezzo - Italy), International Plant Genetic Resources Institute, Rome, Italy.

Zhelev P, Lust N, 1999. Provenance study of Scots pine (Pinus Sylvestris L.) in Belgium. I. Evaluation of phenoptypical traits. Silva Gandavensis 64: 24-36. 